\title{
Elemental Assessment in Economically Important Cirrhinus Mrigala and Labeo Rohita Fish Species Captured from Indus River at Guddu Barrage, Sindh, Pakistan
}

\section{Mushtaque Ali Jakhrani1", Farkhanda Zaman Dayo1, Muhammad Qasim² $^{2}$, Shahid Ali Jakhrani3 ${ }^{3}$, Ashfaque Ahmed Jakhrani1}

\author{
${ }^{1}$ Institute of Chemistry, Shah Abdul Latif University, Khairpur, Sindh, Pakistan \\ ${ }^{2}$ Institute of Chemical Sciences, Bahauddin Zakariya University, Multan, Pakistan \\ ${ }^{3}$ Department of Zoology, Shah Abdul Latif University, Khairpur, Sindh, Pakistan
}

\begin{abstract}
This study aimed to investigate the level of trace and toxic elements (Fe, $\mathrm{Ni}, \mathrm{Cu}, \mathrm{Co}, \mathrm{Mn}, \mathrm{Zn}, \mathrm{Cr}, \mathrm{Cd}$ and $\mathrm{Pb}$ ) in Rohu (labeo rohita) and Mrigala (cirrhinus mrigala) fish species of Indus River at the region of Guddu Barrage, Sindh, Pakistan. The fish samples were collected and processed in the Laboratories of Institute of Chemistry, Shah Abdul Latif University, Khairpur, Sindh, for elemental analysis in gill, muscle and liver of both fish species using Atomic Absorption Spectrophotometer. Results revealed that the level of trace elements was observed within the allowable limit in both Ruho and Mrigala for $\mathrm{Fe}, \mathrm{Cu}, \mathrm{Cr}, \mathrm{Ni}, \mathrm{Zn}, \mathrm{Co}$, and $\mathrm{Mn}$ in the range of

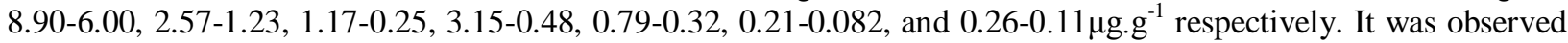
that toxic element chromium was found in gill, liver and muscle of both fish varieties at low level in the range of 1.17-0.25 $\mu \mathrm{g} . \mathrm{g}^{-1}$. However, lead and cadmium were not found in both fish species. It was a good indication for consumer of these fishes of the study area. The observed concentration order of trace and toxic metals was noted as $\mathrm{Fe}>\mathrm{Cu}>\mathrm{Cr}>\mathrm{Ni}>\mathrm{Zn}>\mathrm{Co}>\mathrm{Mn}$ and $\mathrm{Fe}>\mathrm{Cu}>\mathrm{Ni}>\mathrm{Zn}>\mathrm{Cr}>\mathrm{Mn}>$ Co respectively, in homogenious and dried samples of labeo rohita whereas the order was found as $\mathrm{Fe}>\mathrm{Ni}>\mathrm{Cu}>\mathrm{Cr}>\mathrm{Zn}>\mathrm{Mn}>\mathrm{Co}$ and $\mathrm{Fe}>\mathrm{Cu}>\mathrm{Ni}>\mathrm{Zn}$ $>\mathrm{Cr}>\mathrm{Mn}>\mathrm{Co}$ correspondingly, in homogeneous and dried samples of cirrhinus mrigala fish samples correspondimgly. Difference in the order of elements in homogenous samples in comparison to dried samples was probably due to different digestion methods used in the study. It was concluded that concentration of trace elements was found within the RDA guideline as given by FAO/WHO in both fishes of Indus River at Guddu Barrage, District Kashmore, Sindh, Pakistan.
\end{abstract}

Keywords: Heavy Metals; Fish moieties; Dried method; Homogenous method; Indus River

\section{Introduction}

The contamination of freshwater with a wide range of pollutants has become a matter of great concern since last few decades not only because of the threat to public health due to contaminated water supplies but also due to the damage of aquatic life (Adam 2002). Heavy metals seriously contaminate the ecosystems thereby disturbing the aquatic lives bitterly (Idodo 2003). Heavy metals are continuously going to be added into aquatic systems originating from natural sources as well as anthropogenic activities, causing serious threats due to their toxic nature (Nzeve et al. 2014; Eneji et al. 2011). Rapid release of heavy metals in the rivers is responsible for extinction of some species of aquatic fauna. Besides that it is endangering certain other aquatic organisms (Dural et al. 2005).

Fish is considered as one of the most indicative factor for the metals pollution estimation in fresh water ecosystem (Reid and McG 2008). In Pakistan approximately, 193 fish species were found in freshwater fish fauna. Among the significant fish types in Pakistan, 31 fish varieties are inexpensive and easily available in local markets throughout the country. About 8 types are found in icy waters of Karakoram, Hindukush and Himalaya. Main varieties like Labeo rohita and Cirrhinus mrigala are most common commercial fishes available in the country (Maitland and Lyle 2013; Koldewey 2013).

This article is published under the terms of the Creative Commons Attribution License 4.0

Author(s) retain the copyright of this article. Publication rights with Alkhaer Publications.

Published at: http://www.ijsciences.com/pub/issue/2017-08/

DOI: 10.18483/ijSci.1400; Online ISSN: 2305-3925; Print ISSN: 2410-4477 
Labeo rohita is moderately elongated and has bilaterally symmetrical body with cycloid scales, without lateral lobe having dorsal profile more arched than the ventral profile, snout moderately depressed, head without scale projecting beyond mouth, eyes dorsolateral in position, no teeth, jaws extending to front edge of eye (Ali et al. 2010). The Earliest maturity takes place in both sexes within a minimum age of two years. In male fish the attainment of super maturity is four years while in female fish super maturity age is 5 years (Indrajit et al. 2011). The species acquire maturity towards the end of 2nd year in safekeeping throughout the proper feeding. The persuaded reproduction is necessary because the reproduction cannot take place in pond surroundings; (Koldewey et al. 2013).

Cirrhinus mrigala fish is streamlined, bilaterally symmetrical, single pair of short rostral barbells; pharyngeal teeth in three rows, head without scales, beginning of dorsal fin closer to end of muzzle, its deepness corresponding to length of skull (Mendil et al. 2005; Malik et al. 2008). Its growth gradually reduces after the early growth of a maximum period of two years. Meanwhile, mrigala is known to survive till 1.2 decade in water reservoirs. The fertility age of this fish is almost two years. The breeding of mrigala fish needs always fluviatile conditions, therefore, this fish variety breeds in artficial fish ponds (Storelli et al. 2005; Malik et al.2010).

Huge part of food prospective for human inhabitants is comprised of freshwater fishes in the world. Significant foodstuff components are available in fishes for human diet to improve their dietary needs. (Chattopadhyay et al. 2002). Worldwide, fish is used as an important source of valued proteins. One of the most important benefits of fish usage is that it decreases the cholesterol level in the human blood. Fish contains important amino acids and a sufficient quantity of trace metals some of them are important for human health (Shaíato et al. 2011; Njuguna and Kitur 2014). Additionally, 25\% percent protein is going to be taken from fish now a day's (Maitland and Lyle 2013). Because of rising human population and demand of food, the fishes mentioned in this study are nutritionally and economically important in developing countries like Pakistan.

Heavy metals like chromium $(\mathrm{Cr})$, lead $(\mathrm{Pb})$, cadmium $(\mathrm{Cd})$ have been known to have greater density and hazardous effects even at low concentrations. Some trace elements like copper $(\mathrm{Cu})$ and zinc $(\mathrm{Zn})$ have also been recognized as heavy metals but these elements are very much necessary to sustainable human body metabolism, however, if taken at higher concentrations these elements might be proved poisonous. Due to bioaccumulation in organisms, the greater amount of heavy metals is harmful as these weaken the ecological unit (Chattopadhyay et al. 2002; Idodo 2003).

In different organs of aquatic organisms especially in fishes, metals do accumulate which in turn might transfer into the human metabolism via effected fish consumption creating serious health problems (Nzeve et al. 2014). Fish accumulate comparatively high amount of heavy metals as located at the high trophic level in food web. However, this amount is quite high in some cases (Kakulu et al. 1987). Once they enter the aquatic environment, they are taken up through different organs of the fish and other aquatic organisms due to affinity between them (Er.Long et al. 1998). Because of non-biodegradable nature of metals, the concentration of heavy metals might occur in fish tissues by means of bio-sorption and metabolic processes (Stanburg et al. 1978). Iron, copper and zinc have a vital role among heavy metals and are essential for fish metabolism, while other metals like mercury, cadmium and lead do not have known role in the normal fish physiology (Canli and Atli, 2003).

In present research, upper and lower level of trace, toxic and essential elements in liver, muscle and gill tissues of two economically and commercially available fresh water fish species was evaluated in the study area as these fish species were being extensively consumed by the common men of Guddu-Kashmore and its neighbouring areas like Kandhkot, Rojhan, Rajanpur, Sanjarpur, Nawazabad, Chaok Sawaitra and Sadiqabad Punjab. Moreover, these fishes have a valuable attention to our employment, earnings and diet. Interpretation of harmful metals in organs of commonly consumable fishes of Guddu Barrage to have insight knowledge about toxic metallic contamination was very much necessary due to its consumption in multicity and for common people health perspectives. For maximal consumption and better results, the respective water quality needs to be monitored continuously because continuous use of fishes containing low levels of hazardous metals may possibly damage the health of human's population.

\section{Materials and Methods \\ 2.1 Study Area}

District Kashmore is located at North-East of the Province of Sindh. The study area is lying at the border of Baluchistan and Punjab provinces. The irrigation of the district depends upon water supply through Gudddu barrage. Almost, there is availability of excess water at the barrage. The most popular product of the Kashmore District is the fish which is caught by the local fishermen from the river easily. The map of study area and photographic view of Indus River at Guddu Barrage is given in Figure-1. 


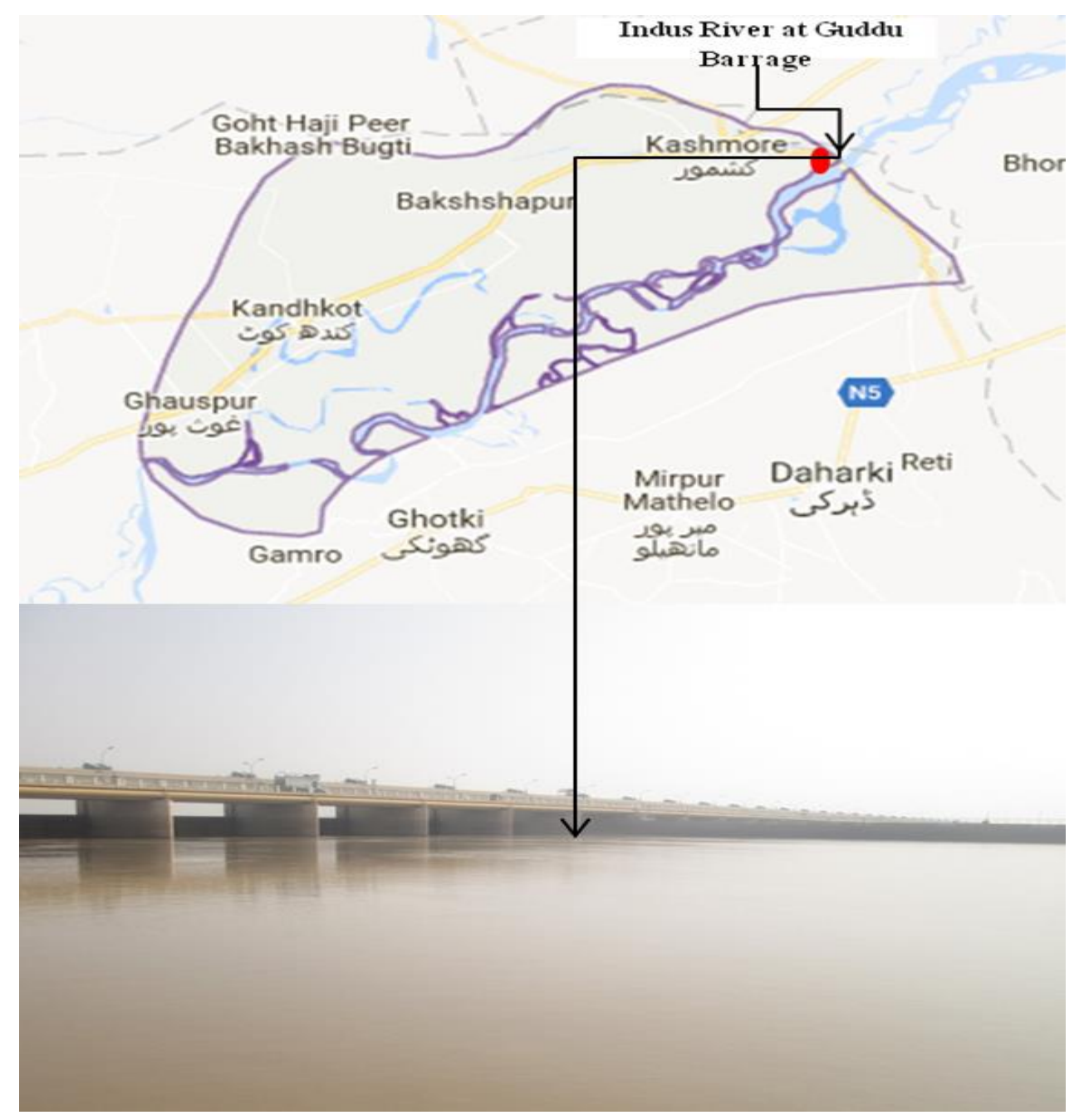

Figure 1. Map of study area and photographic view of Indus River at Guddu Barrage.

\subsection{Samples Description}

Two types freshwater fish samples; Labeo Rohita and Cirrhinus Mrigala were used in this study. The fish species were collected from professional fishermen at Indus River Guddu Barrage, District Kashmore, Sindh, Pakistan. For each species sixty fish samples were netted from the river through fishermen. The fishes which were not matched with standard sizes were thrown in the river on the spot with care and the matched samples were brought to the laboratory in ice cooled boxes and frozen below $-20{ }^{\circ} \mathrm{C}$ until dissection. Total fish length and weight were measured up to the nearest millimeters and grams respectively. Each sample collected from the Indus River was dissected for its gill, liver and muscle tissues and subjected to digestion as explained below.

\subsubsection{Dried Method of Digestion}

Dissection of eight gram of the biological specimen of both fish varieties was carried out for gills, liver and muscles. The samples were dried at $80{ }^{\circ} \mathrm{C}$, after drying; the samples were grinded in a grinder machine. The biological specimen was further dried in desiccators using alumina as desiccant. The samples were then treated with $\mathrm{HNO} 365 \%$ (Nitric acid 65 percent) $\mathrm{HCl}$ (hydrochloric acid) and $\mathrm{H}_{2} \mathrm{O}_{2}$ $30 \%$ (hydrogen peroxide 30 percent). To make the colour clear, the acidified samples were kept hot plate for half an hour at $130^{\circ} \mathrm{C}$. The specimen samples were filtered and diluted upto $50 \mathrm{ml}$ with double distilled water in volumetric flasks for gill and muscle tissue samples only. However, the volume of the sample was concentrated to $25 \mathrm{ml}$ for liver specimen for the ease of lowest level detection. The standard solutions were obtained through the same acid matrix and the blank samples (without any fish contents) were digested by the same procedure as mentioned above.

\subsubsection{Homogeneous Method of Digestion}

The dissected tissues (muscle, gill and liver) were homogenized and placed in a $300 \mathrm{ml}$ digestion tube. A mixture of tri acids containing $14 \mathrm{ml} \mathrm{H}_{2} \mathrm{O}_{2} \quad(35$ percent), $6 \mathrm{ml} \mathrm{Nitric} \mathrm{Acid} \mathrm{and} 2 \mathrm{ml} \mathrm{HCl}$ was used for 
Elemental Assessment in Economically Important Cirrhinus Mrigala and Labeo Rohita Fish Species Captured from Indus River at Guddu Barrage, Sindh, Pakistan

digestion. To make the colour clear, the acidified samples were kept on hot plate for half an hour at $130^{\circ} \mathrm{C}$. The specimen samples were filtered after getting normal temperature and diluted upto $50 \mathrm{ml}$ with double distilled water in volumetric flasks. The blank reagents were digested by the same procedure as mentioned above.

\subsection{Metals Analysis}

Metals concentrations were analyzed using Atomic Absorption Spectrophotometer (AA 100-Analyst, Perkin Elmer, USA). Heavy metals concentrations of iron $(\mathrm{Fe})$, copper $(\mathrm{Cu})$, zinc $(\mathrm{Zn})$, nickel $(\mathrm{Ni})$, copper $(\mathrm{Cu})$, manganese $(\mathrm{Mn})$, chromium $(\mathrm{Cr})$, cadmium $(\mathrm{Cd})$ and lead $(\mathrm{Pb})$ in the muscle, liver and gill tissues of each fish sample were analyzed in triplicate. Fe, $\mathrm{Ni}, \mathrm{Co}, \mathrm{Mn}$ and $\mathrm{Zn}$ were determined using airacetylene flame. $\mathrm{Cd}, \mathrm{Cr}, \mathrm{Pb}$ and $\mathrm{Cu}$ were determined by using nitrous oxide- acetylene flame. The results were presented as $\mu \mathrm{g} . \mathrm{g}-1$. A range of analytical standards for each metal was prepared using Merck stock solutions. Each sample was analyzed three times for all metals. Analytical blanks were run in the same way as the samples.

\section{Results}

Data obtained was statistically analyzed and the results were expressed as mean of triplicate values. The concentrations of iron, zinc, copper, nickel, manganese, cobalt and chromium in different tissues of Mrigala (cirrhinus mrigala) and Rohu (Labeo rohita) fish species are given in Table-1 and Table-2 respectively.
Maximum iron contents were found in FML-4 (6.0 $\left.\mu \mathrm{g} \cdot \mathrm{g}^{-1}\right)$ and FML-2 $\left(8.3 \mu \mathrm{g} \cdot \mathrm{g}^{-1}\right)$ of homogeneous and dried samples of Mrigala fish respectively, as shown in Table-1. In case of Rohu fish, maximum iron contents were found in FRM-5 $\left(7.6 \mu \mathrm{g} . \mathrm{g}^{-1}\right)$ \& FRM-5 $\left(8.9 \mu \mathrm{g} \cdot \mathrm{g}^{-1}\right)$ of homogeneous and dried samples respectively, as shown in Table-2.

The highest concentration of $\mathrm{Zn}, \mathrm{Cu}, \mathrm{Ni}, \mathrm{Mn}, \mathrm{Co}$, and Cr was found in FMM-5 (0.32 $\left.\mu \mathrm{g} . \mathrm{g}^{-1}\right)$, FML-3 $(2.57$ $\left.\mu \mathrm{g} . \mathrm{g}^{-1}\right)$, FML-5 (3.15 $\left.\mu \mathrm{g} . \mathrm{g}^{-1}\right)$, FML-5 (0.26 $\left.\mu \mathrm{g} . \mathrm{g}^{-1}\right)$, FMM-1 (0.11 $\left.\mu \mathrm{g}^{-\mathrm{g}^{-1}}\right)$ \& FML-3 (0.71 $\left.\mu \mathrm{g} . \mathrm{g}^{-1}\right)$ of homogeneous samples and in FMM-5 $\left(0.45 \mu \mathrm{g} \cdot \mathrm{g}^{-1}\right)$, FML-4 (1.23 $\left.\mu \mathrm{g} \cdot \mathrm{g}^{-1}\right)$, FMG-3 (0.48 $\left.\mu \mathrm{g} \cdot \mathrm{g}^{-1}\right)$, FMM-5 $\left(0.17 \mu \mathrm{g} . \mathrm{g}^{-1}\right)$, FMG-5 $\left(0.08 \mu \mathrm{g} . \mathrm{g}^{-1}\right)$ \& FMM-3 $(0.25$ $\left.\mu \mathrm{g} \cdot \mathrm{g}^{-1}\right)$ of dried samples of Mrigala fish correspondingly as shown in Table-1.

In case of Rohu fish, the maximum concentration of $\mathrm{Zn}, \mathrm{Cu}, \mathrm{Ni}, \mathrm{Mn}, \mathrm{Co}$, and $\mathrm{Cr}$ was found in FRL-3 $\left(0.79 \mu \mathrm{g} . \mathrm{g}^{-1}\right)$, FRM-4 (1.37 $\left.\mu \mathrm{g} . \mathrm{g}^{-1}\right)$, FRG-5 (0.82 $\left.\mu \mathrm{g} . \mathrm{g}^{-1}\right)$, FRG-5 (0.12 $\left.\mu \mathrm{g} . \mathrm{g}^{-1}\right)$, FRM-2 $\left(0.21 \mu \mathrm{g} . \mathrm{g}^{-1}\right)$ \& FRM-5 $\left(1.17 \mu \mathrm{g} . \mathrm{g}^{-1}\right)$ of homogeneous samples and in

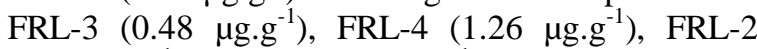
$\left(0.49 \mu \mathrm{g} \cdot \mathrm{g}^{-1}\right)$, FRL-5 $\left(0.11 \mu \mathrm{g} \cdot \mathrm{g}^{-1}\right)$, FRL-3 $\left(0.14 \mu \mathrm{g} \cdot \mathrm{g}^{-}\right.$ $\left.{ }^{1}\right) \quad \&$ FRM-1 $\left(0.35 \mu \mathrm{g} \cdot \mathrm{g}^{-1}\right)$ of dried samples respectively, as shown in Table-2. Analytical ranges of trace and toxic elements in biological specimens of Rohu fish are given in Table 3-4 and those of Mrigala fish are given in Table 5-6. Average ranges of analytical data of biological specimens of Mrigala fish and Rohu Fish are given in Table-7.

\begin{tabular}{|c|c|c|c|c|c|c|c|c|c|c|c|c|c|c|c|}
\hline \multirow[b]{2}{*}{$\begin{array}{l}\text { Mrigala } \\
\text { Fish }\end{array}$} & \multicolumn{3}{|c|}{ Fe $\mu \mathrm{g} \cdot \mathrm{g}^{-1}$} & \multicolumn{2}{|c|}{ Zn $\mu \mathrm{g} \cdot \mathrm{g}^{-1}$} & \multicolumn{2}{|c|}{ Cu $\mu \mathrm{g} \cdot \mathrm{g}^{-1}$} & \multicolumn{2}{|c|}{ Ni $\mu \mathrm{g} \cdot \mathrm{g}^{-1}$} & \multicolumn{2}{|c|}{ Mn $\mu \mathrm{g} \cdot \mathrm{g}^{-1}$} & \multicolumn{2}{|c|}{$\cos \mu \mathrm{g} \cdot \mathrm{g}^{-1}$} & \multicolumn{2}{|c|}{ Cr $\mu \mathrm{g} \cdot \mathrm{g}^{-1}$} \\
\hline & Code & Homo & Dried & Homo & Dried & Homo & Dried & Homo & Dried & Homo & Dried & Homo & Dried & Homo & Dried \\
\hline \multirow{5}{*}{ Gill } & $F M G-1$ & 3.9 & 2.5 & 0.15 & 0.07 & 1.67 & 0.45 & 0.7 & 0.28 & 0.09 & 0.06 & 0.08 & 0.037 & 0.26 & 0.18 \\
\hline & $F M G-2$ & 4.0 & 2.3 & 0.2 & 0.08 & 1.53 & 0.69 & 0.7 & 0.29 & 0.10 & 0.13 & 0.07 & 0.035 & 0.27 & 0.17 \\
\hline & $F M G-3$ & 5.7 & 3.6 & 0.16 & 0.05 & 1.29 & 0.53 & 0.41 & 0.28 & 0.24 & 0.092 & 0.08 & 0.035 & 0.47 & 0.17 \\
\hline & FMG-4 & 5.7 & 2.8 & 0.23 & 0.20 & 1.08 & 0.58 & 0.9 & 0.48 & 0.18 & 0.121 & 0.07 & 0.080 & 0.48 & 0.23 \\
\hline & FMG-5 & 5.7 & 3.8 & 0.29 & 0.26 & 0.48 & 0.81 & 0.75 & 0.47 & 0.24 & 0.104 & 0.06 & 0.082 & 0.44 & 0.24 \\
\hline \multirow{5}{*}{ Liver } & $F M L-1$ & $\frac{2.1}{3.0}$ & $\frac{2.0}{5.9}$ & 0.29 & 0.18 & 0.48 & 0.01 & 1.05 & 0.45 & 0.104 & 0.104 & 0.07 & 0.002 & 0.27 & 0.18 \\
\hline & $F M L-2$ & 5.8 & 8.3 & 0.08 & 0.15 & 2.08 & 0.85 & 1.35 & 0.39 & 0.083 & 0.058 & 0.07 & 0.08 & 0.46 & 0.23 \\
\hline & FML-3 & 5.7 & 0.6 & 0.16 & 0.19 & 2.57 & 0.98 & 2.85 & 0.19 & 0.117 & 0.119 & 0.08 & 0.08 & 0.71 & 0.18 \\
\hline & FML-4 & 6.0 & 4.0 & 0.15 & 0.13 & 1.33 & 1.23 & 2.65 & 0.11 & 0.121 & 0.060 & 0.05 & 0.07 & 0.48 & 0.23 \\
\hline & $F M L-5$ & 3.0 & 4.2 & 0.17 & 0.11 & 1.13 & 0.84 & 3.15 & 0.09 & 0.263 & 0.058 & 0.07 & 0.5 & 0.47 & 0.24 \\
\hline \multirow{5}{*}{ Muscle } & FMM-1 & $\frac{0.0}{1.6}$ & $\frac{7.2}{2.1}$ & 0.08 & 0.11 & 0.88 & 0.43 & 1.35 & 0.15 & 0.200 & 0.060 & 0.11 & 0.09 & 0.4 & 0.15 \\
\hline & FMM-2 & 1.7 & 2.2 & 0.16 & 0.13 & 0.55 & 0.85 & 2.05 & 0.25 & 0.12 & 0.058 & 0.08 & 0.03 & 0.5 & 0.22 \\
\hline & $F M M-3$ & 5.8 & 5.0 & 0.18 & 0.14 & 0.55 & 0.98 & 2.85 & 0.15 & 0.12 & 0.121 & 0.07 & 0.06 & 0.5 & 0.25 \\
\hline & FMM-4 & 1.7 & 3.0 & 0.22 & 0.18 & 0.58 & 0.98 & 2.61 & 0.29 & 0.12 & 0.1119 & 0.07 & 0.08 & 0.3 & 0.18 \\
\hline & $F M M-5$ & 1.8 & 2.9 & 0.32 & 0.45 & 0.65 & 0.98 & 2.85 & 0.28 & 0.23 & 0.179 & 0.07 & 0.07 & 0.5 & 0.23 \\
\hline
\end{tabular}

Table. 2. Concentration of trace and toxic elements in biological specimen of Rohu fish, Guddu Barrage, Sindh, Pakistan

\begin{tabular}{|c|c|c|c|c|c|c|c|c|c|c|c|c|c|c|c|}
\hline \multirow[b]{2}{*}{ Rohu Fish } & \multirow[b]{2}{*}{ Code } & \multicolumn{2}{|c|}{ Fe $\mu \mathrm{g} \cdot \mathrm{g}^{-1}$} & \multicolumn{2}{|c|}{ Zn $\mu \mathrm{g} \cdot \mathrm{g}^{-1}$} & \multicolumn{2}{|c|}{$\mathrm{Cu} \mu \mathrm{g} \cdot \mathrm{g}^{-1}$} & \multicolumn{2}{|c|}{$\mathrm{Ni} \mu \mathrm{g} \cdot \mathrm{g}^{-1}$} & \multicolumn{2}{|c|}{ Mn $\mu \mathrm{g} \cdot \mathrm{g}^{-1}$} & \multicolumn{2}{|c|}{ Co $\mu \mathrm{g} \cdot \mathrm{g}^{-1}$} & \multicolumn{2}{|c|}{ Cr $\mu \mathrm{g} \cdot \mathrm{g}^{-1}$} \\
\hline & & Homo & Dried & Homo & Dried & Homo & Dried & Homo & Dried & Homo & Dried & Homo & Dried & Homo & Dried \\
\hline \multirow{5}{*}{ Gill } & FRG-1 & 3.2 & 2.3 & 0.08 & 0.039 & 0.85 & 0.7 & 0.5 & 0.012 & 0.104 & 0.061 & 0.07 & 0.011 & 0.013 & 0.25 \\
\hline & FRG-2 & 1.8 & 2.2 & 0.19 & 0.072 & 0.58 & 0.46 & 0.63 & 0.021 & 0.117 & 0.052 & 0.07 & 0.021 & 0.032 & 0.23 \\
\hline & FRG-3 & 3.6 & 2.1 & 0.54 & 0.151 & 0.40 & 0.33 & 0.75 & 0.042 & 0.121 & 0.053 & 0.16 & 0.031 & 0.041 & 0.24 \\
\hline & FRG-4 & 3.7 & 2.2 & 0.46 & 0.414 & 0.58 & 0.73 & 0.54 & 0.033 & 0.117 & 0.033 & 0.08 & 0.022 & 0.071 & 0.23 \\
\hline & FRG-5 & 4.5 & 2.1 & 0.07 & 0.053 & 0.90 & 1.04 & 0.82 & 0.054 & 0.121 & 0.021 & 0.16 & 0.042 & 0.042 & 0.24 \\
\hline \multirow{5}{*}{ Liver } & FRL-1 & 4.5 & 2.1 & 0.26 & 0.09 & 0.38 & 0.35 & 0.05 & 0.471 & 0.021 & 0.042 & 0.03 & 0.078 & 0.031 & 0.18 \\
\hline & FRL-2 & 4.6 & 2.3 & 0.26 & 0.15 & 0.40 & 0.73 & 0.07 & 0.492 & 0.011 & 0.058 & 0.01 & 0.082 & 0.053 & 0.21 \\
\hline & FRL-3 & 5.7 & 2.2 & 0.79 & 0.48 & 0.63 & 0.98 & 0.04 & 0.471 & 0.021 & 0.060 & 0.08 & 0.084 & 0.064 & 0.19 \\
\hline & FRL-4 & 4.6 & $\frac{2.5}{2.5}$ & 0.48 & 0.45 & 0.70 & 1.04 & 0.32 & 0.321 & 0.042 & 0.060 & 0.03 & 0.082 & 0.061 & 0.17 \\
\hline & FRL-5 & 4.5 & 2.3 & 0.10 & 0.28 & 0.55 & 1.26 & 0.33 & 0.051 & 0.054 & 0.119 & 0.04 & 0.084 & 0.043 & 0.18 \\
\hline \multirow{5}{*}{ Muscle } & FRM-1 & 3.7 & $\frac{1.1}{2.1}$ & 0.19 & 0.05 & 0.38 & 0.67 & 0.02 & 0.052 & 0.055 & 0.042 & 0.07 & 0.082 & 0.049 & 0.35 \\
\hline & FRM-2 & 4.6 & 2.3 & 0.26 & 0.05 & 0.58 & 0.79 & 0.03 & 0.032 & 0.072 & 0.043 & 0.07 & 0.052 & 1.08 & 0.23 \\
\hline & FRM-3 & 4.5 & 2.6 & 0.43 & 0.11 & 0.43 & 0.81 & 0.04 & 0.012 & 0.062 & 0.052 & 0.08 & 0.14 & 0.46 & 0.25 \\
\hline & FRM-4 & 6.0 & 6.6 & 0.43 & 0.16 & 1.37 & 0.78 & 0.05 & 0.062 & 0.032 & 0.031 & 0.21 & 0.081 & 0.48 & 0.25 \\
\hline & FRM-5 & 7.6 & 8.9 & 0.20 & 0.19 & 0.82 & 0.98 & 0.04 & 0.032 & 0.045 & 0.036 & 0.08 & 0.071 & 1.17 & 0.35 \\
\hline
\end{tabular}


Elemental Assessment in Economically Important Cirrhinus Mrigala and Labeo Rohita Fish Species Captured from Indus River at Guddu Barrage, Sindh, Pakistan

Table.3. Analytical ranges of trace and toxic elements in biological specimens of Rohu fish Guddu Barrage, Sindh, Pakistan

\begin{tabular}{|c|c|c|c|c|c|c|c|c|c|c|c|c|c|c|c|c|c|c|c|}
\hline & & & & $\mathrm{Fe}$ & g.g. & & & & & $\mathrm{Zn}$ & $g^{-1}$ & & & & & $\mathrm{Cu}$ & g. $g^{-1}$ & & \\
\hline & & & $\begin{array}{l}\text { mo dig } \\
\text { meth }\end{array}$ & $\begin{array}{l}\text { stion } \\
\text { d }\end{array}$ & & $\begin{array}{l}\text { ed dige } \\
\text { metho }\end{array}$ & & & $\begin{array}{l}\text { no dige } \\
\text { metho }\end{array}$ & ition & & $\begin{array}{ll}\text { ed dige } \\
\text { mathe }\end{array}$ & tion & & $\begin{array}{l}\text { no dige } \\
\text { metho }\end{array}$ & & & $\begin{array}{l}\text { d diges } \\
\text { metho }\end{array}$ & \\
\hline & & Min & Max & Mean & Min & Max & Mean & Min & $\operatorname{Max}$ & Mean & Min & Max & Mean & Min & $\operatorname{Max}$ & Mean & Min & Max & Mean \\
\hline Gill & FRG-1 & 3.10 & 4.50 & 3.73 & 2.1 & 2.6 & 2.35 & 0.05 & 0.11 & 0.08 & 0.038 & 0.041 & 0.04 & 0.84 & 0.89 & 0.86 & 0.68 & 0.75 & 0.71 \\
\hline & $F R G-2$ & 1.5 & 2.2 & 1.86 & 2.1 & 2.6 & 2.39 & 0.17 & 0.21 & 0.19 & 0.07 & 0.08 & 0.07 & 0.55 & 0.61 & 0.58 & 0.45 & 0.5 & 0.47 \\
\hline & $F R G-3$ & 3.2 & 4.2 & 3.66 & 2.1 & 2.5 & 2.32 & 0.53 & 0.58 & 0.553 & 0.15 & 0.16 & 0.15 & 0.38 & 0.45 & 0.42 & 0.31 & & 0.34 \\
\hline & & $\frac{0.2}{3.3}$ & 4.28 & 3.78 & 2.1 & 2.6 & 2.37 & $\frac{0.34}{0.44}$ & $\frac{0.50}{0.5}$ & $\frac{0.553}{0.47}$ & $\frac{0.15}{0.412}$ & $\frac{.10}{0.416}$ & $\frac{0.15}{0.41}$ & $\frac{0.38}{0.54}$ & $\frac{0.45}{0.6}$ & $\frac{0.42}{0.57}$ & $\frac{0.31}{0.71}$ & $\frac{0.37}{0.75}$ & 0.04 \\
\hline & $F R G-5$ & 4.2 & 4.9 & 4.49 & 2.1 & 2.6 & 2.37 & 0.07 & 0.11 & 0.09 & 0.09 & 0.14 & 0.11 & 0.87 & 0.92 & 0.90 & 1.01 & 1.06 & 1.04 \\
\hline Liver & FRL-1 & 4.2 & 4.9 & 4.53 & 2.1 & 2.6 & 2.36 & 0.25 & 0.3 & 0.28 & 0.09 & 0.096 & 0.09 & 0.35 & 0.41 & 0.38 & 0.32 & 0.38 & 0.35 \\
\hline & $F R L-2$ & 4.2 & 4.9 & 4.53 & 2.1 & 2.6 & 2.38 & 0.25 & 0.29 & 0.27 & 0.13 & & & 0.38 & 0.44 & & 0.71 & 0.77 & 0.74 \\
\hline & & 5.4 & 5.9 & 5.6 & & 2.7 & & 0.75 & 0.81 & 0.78 & 0.45 & 0.49 & 0.47 & 0.6 & 0.66 & 0.63 & 0.94 & 0.99 & 0.96 \\
\hline & $F R L-4$ & 4.4 & 4.9 & 4.7 & 2.2 & 2.9 & 2.6 & 0.45 & 0.51 & 0.48 & 0.44 & 0.49 & 0.47 & 0.68 & 0.75 & 0.71 & 1.04 & 1.09 & 1.06 \\
\hline & FRL-5 & 4.3 & 4.9 & 4.6 & 2.1 & 2.7 & 2.4 & 0.1 & 0.14 & 0.118 & 0.25 & 0.31 & 0.28 & 0.54 & 0.59 & 0.56 & 1.22 & 1.27 & 1.25 \\
\hline Muscle & FRM-1 & 3.5 & 3.9 & 3.7 & 2.1 & 2.6 & 2.3 & 0.18 & 0.23 & 0.20 & 0.05 & 0.06 & 0.05 & 0.35 & 0.41 & 0.38 & 0.63 & 0.68 & 0.66 \\
\hline & FRM-2 & 4.3 & 4.9 & 4.6 & 2.2 & 2.8 & 2.5 & 0.25 & 0.29 & 0.27 & 0.048 & 0.053 & 0.05 & 0.55 & 0.6 & 0.57 & 0.74 & 0.79 & 0.77 \\
\hline & & 4.4 & 4.9 & 4.6 & 2.5 & 3.2 & 2.8 & 0.42 & 0.46 & 0.44 & 0.1 & 0.15 & 0.13 & 0.41 & 0.46 & 0.44 & 0.8 & 0.85 & 0.83 \\
\hline & FRM-4 & 5.8 & 6.3 & 6.0 & 6.2 & 6.7 & 6.5 & 0.43 & 0.48 & 0.45 & 0.15 & 0.2 & 0.17 & 1.34 & 1.4 & 1.37 & 0.74 & 0.78 & 0.76 \\
\hline & FRM-5 & 7.2 & 7.8 & 7.5 & 8.5 & 8.9 & 8.7 & 0.2 & 0.25 & 0.22 & 0.17 & 0.22 & 0.20 & 0.8 & 0.86 & 0.83 & 0.94 & 0.99 & 0.97 \\
\hline
\end{tabular}

Table.4. Analytical ranges of trace and toxic elements in biological specimens of Rohu fish Guddu Barrage, Sindh, Pakistan

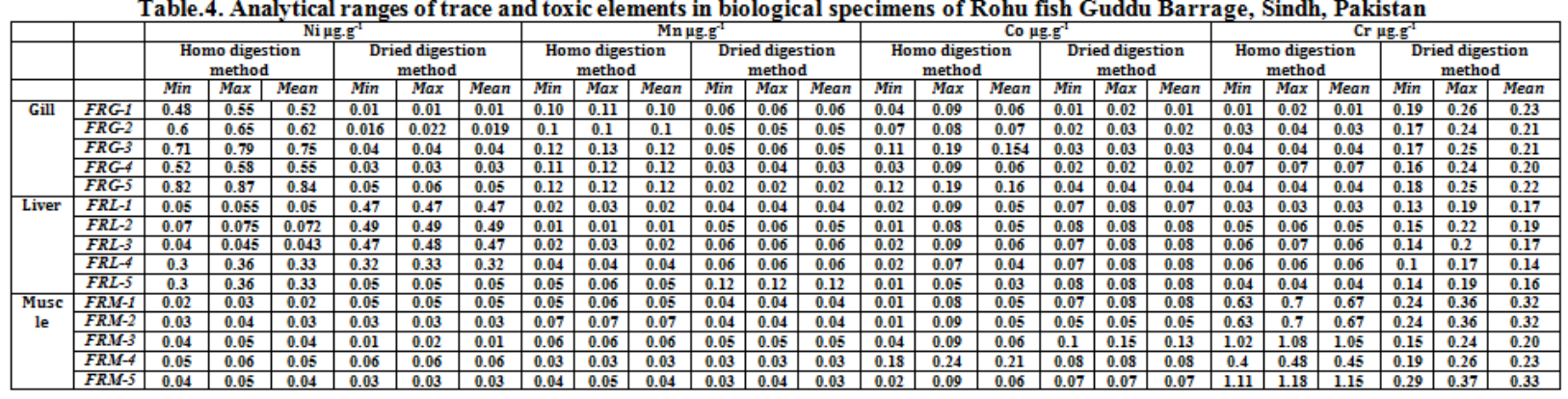

\begin{tabular}{l} 
Table.5. Analytical ranges of trace and toxic elements in biological specimens of Mrigala fish of Guddu Barrage, Sindh, Pakistan \\
\begin{tabular}{|c|c|c|c|c|c|c|c|c|c|c|c|c|c|c|c|c|}
\hline \\
\hline
\end{tabular} \\
\hline
\end{tabular}

Table.6. Analytical ranges of trace and toxic elements in biological specimens of Mrigala fish of Guddu Barrage, Sindh, Pakistan

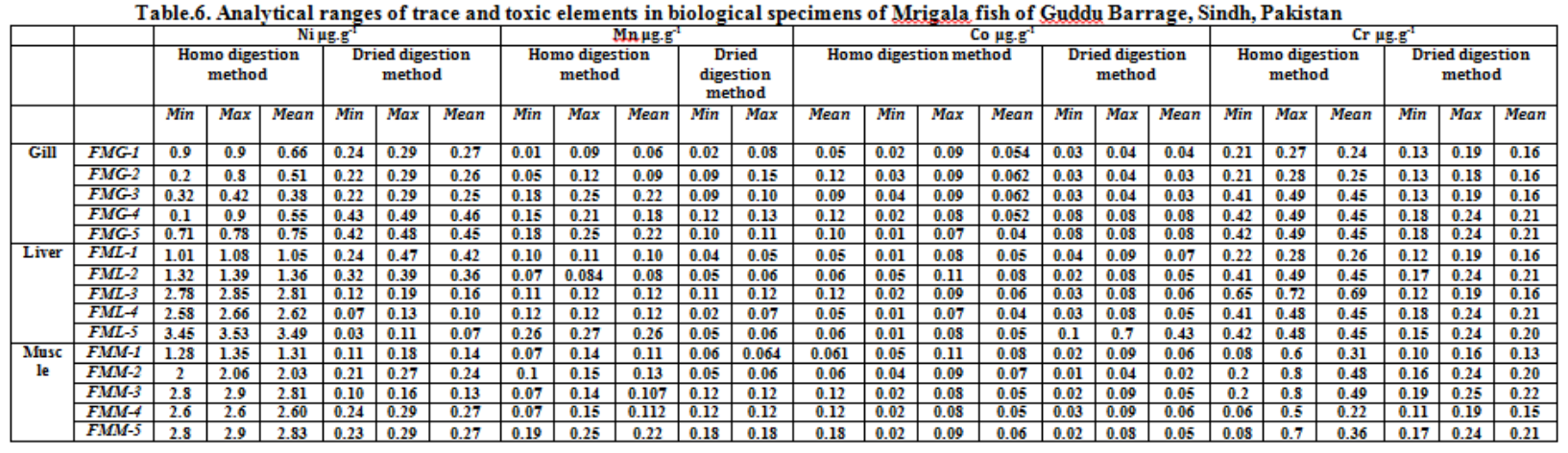

Table, 7. Average ranges of data of biological specimens of Mrigala fish and Rohu Fish Guddu Barrage, Sindh, Pakistan

\begin{tabular}{|c|c|c|c|c|c|c|c|c|c|c|c|c|c|}
\hline & \multirow{3}{*}{$\begin{array}{c}\text { Recommended } \\
\text { values } \\
\text { WHO(2004) }\end{array}$} & \multicolumn{6}{|c|}{ Rohu $\mathrm{n}=300^{*}$} & \multicolumn{6}{|c|}{ Mrigala $n=300^{2}$} \\
\hline & & \multicolumn{3}{|c|}{ Homon $=150^{\circ}$} & \multicolumn{3}{|c|}{ Dried $n=150^{\circ}$} & \multicolumn{3}{|c|}{ Homon $=150^{*}$} & \multicolumn{3}{|c|}{ Dried $n=150^{\circ}$} \\
\hline & & Min & Max & Average & $\operatorname{Min}$ & Max & Average & $\operatorname{Min}$ & Max & Average & $\operatorname{Min}$ & Max & Average \\
\hline Fe & $0.2-11 \mathrm{mg} / \mathrm{d} \mathrm{ay}$ & 1.5 & 7.8 & 4.5 & 2.1 & 8.9 & 3.1 & 1.2 & 6.1 & 4.0 & 0.2 & 8.4 & 3.4 \\
\hline $\mathbf{Z n}_{\mathbf{n}}$ & $8 \mathrm{mg}-9 \mathrm{mg} / \mathrm{day}$ & 0.05 & 0.81 & 0.33 & 0.04 & 0.49 & 0.19 & 0.04 & 0.9 & 0.19 & 0.01 & 0.46 & 0.15 \\
\hline $\mathrm{Cu}$ & $900 \mathrm{ug} / \mathrm{day}$ & 0.35 & 1.4 & 0.64 & 0.31 & 1.27 & 0.78 & 0.4 & 2.6 & 1.14 & 0.4 & 1.3 & 0.8 \\
\hline $\mathrm{Ni}$ & $0.2-1 \mathrm{mg} / \mathrm{day}$ & 0.02 & 0.87 & 0.29 & 0.01 & 0.49 & 0.11 & 0.1 & 3.5 & 1.7 & 0.03 & 0.5 & 0.3 \\
\hline Mn & $1.6-2.2 \mathrm{mg} / \mathrm{day}$ & 0.01 & 0.13 & 0.07 & 0.02 & 0.12 & 0.05 & 0.01 & 0.27 & 0.14 & 0.02 & 0.18 & 0.09 \\
\hline$C_{0}$ & $10-20 \mu \mathrm{g} / \mathrm{day}$ & 0.01 & 0.24 & 0.08 & 0.01 & 0.15 & 0.06 & 0.01 & 0.11 & 0.06 & 0.01 & 0.7 & 0.08 \\
\hline $\mathrm{Cr}$ & $5.5-24 \mathrm{mg} / \mathrm{day}$ & 0.01 & 1.18 & 0.28 & 0.1 & 0.37 & 0.21 & 0.1 & 0.8 & 0.4 & 0.1 & 0.3 & 0.2 \\
\hline
\end{tabular}




\section{Discussions}

Figure-2 shows comparison of average concentration of $\mathrm{Fe}$ in gill, liver and Muscle tissues of Rohu and Mrigala fish species. It was observed that higher concentrations of Fe were found in liver and muscle tissues in as compared to gill tissues in Rohu fish but in case of Mrigala fish in homogenous samples higher contents of $\mathrm{Fe}$ were found as compared to dried samples in Gill of Mrigala fish .higher concentrations were found in gill and liver tissues.

Generally, higher concentration of iron was observed in homogenous samples as compared to dried samples in in biological specimen of Mrigala and Rohu fish. Many researchers have studied accumulation of metals in the tissues of fishes. Different factors like temperature, seasonal changes, physico-chemical status of water might cause metal accumulation in the fish tissues (Kargin1996; Jezierska and Witeska 2001).

The concentration of zinc was noted highest in liver tissues of Rohu fish as compared to gill and muscle tissues. The level of zinc was found higher in homogeneous samples of gill and muscle tissues in comparison to dried samples. The concentration of Zinc in various organs of Rohu and Mrigala fishes in their homogeneous and dried samples is given in Figure-3.

The concentrations of copper were noted highest in liver and muscle tissues of Mrigala fish as compared to gill tissues as shown in Figure-4. Generally, in Rohun fish highest concentration was found in dried samples of liver tissues as compared to gill and muscle tissues. Higher levels of $\mathrm{Cu}$ were generally observed in dried samples of Rohu fish and homogeneous samples of Mrigala fish samples.

The maximum level of cobalt was in dried samples of Mrigala fish as compared to gill liver and muscle tissues of Rohu fish as shown in Figure-5. In Rohu fish higher concentrations of Co were observed in homogeneous samples of gill and muscle tissues in comparison to liver tissues. At the beginning of exposure, the gills are good sites for metal ions uptake befor entering into other parts of the organisms (Jezierska \& Witeska, 2001).

Figure-6 shows that manganese (Mn) concentrations were found highest in dried samples of Mrigala fish. Negligible concentrations of $\mathrm{Mn}$ were observed in homogeneous and dried samples of muscle and gill tissues of Rohu fish.

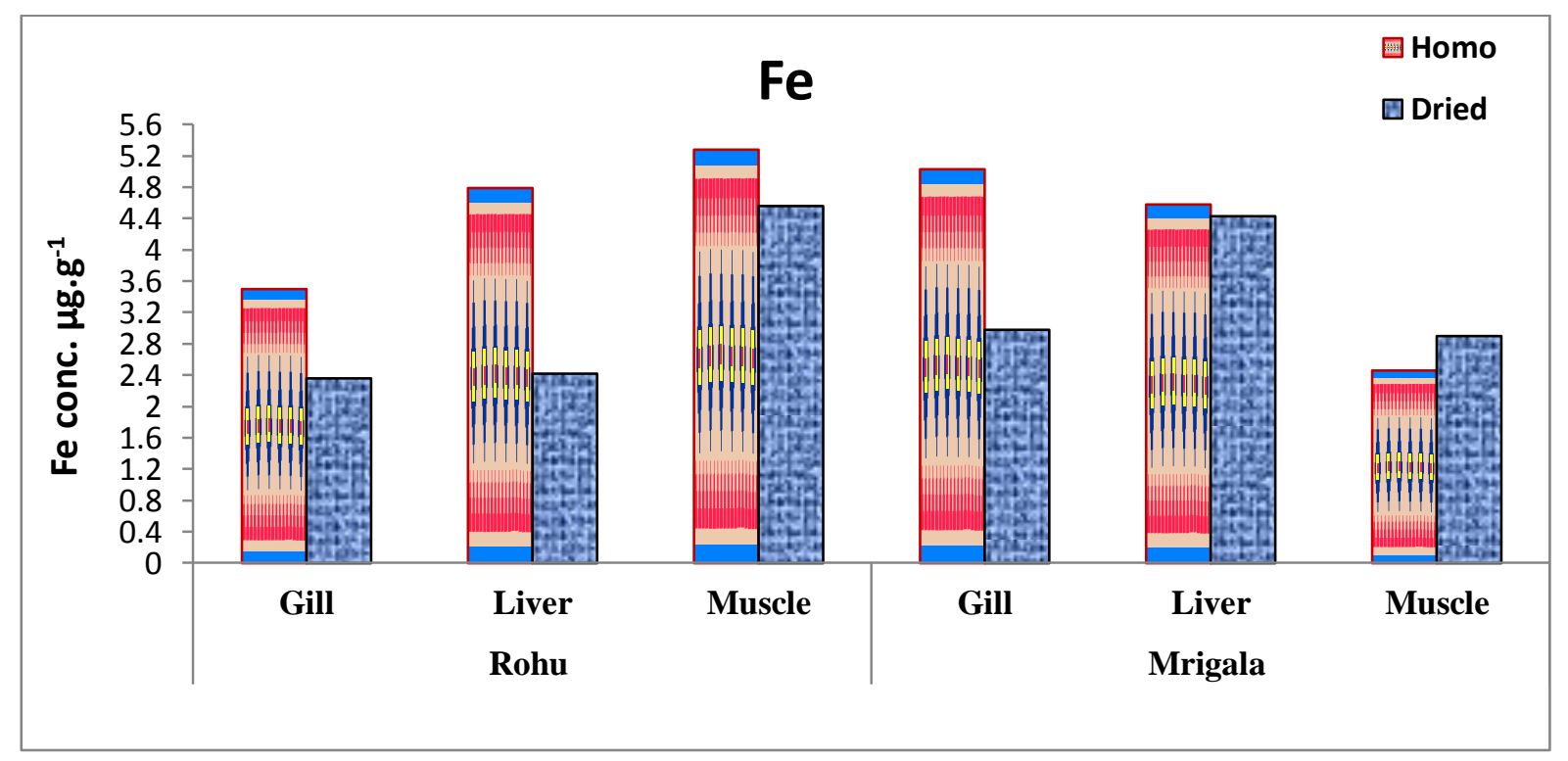

Figure 2: Comparison of average iron concentrations in gill, liver and muscle tissues of biological specimen of Rohu and Mrigala fish species. 


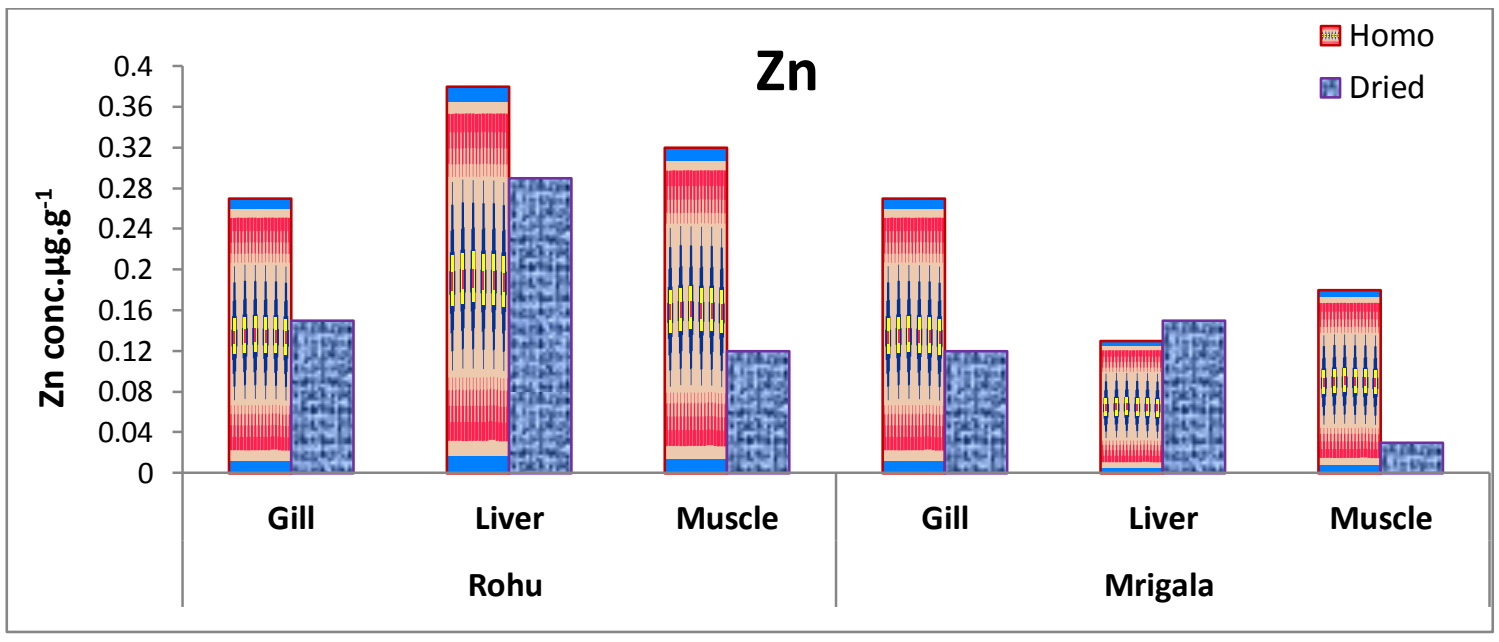

Figure 3: Comparison of average zinc concentrations in gill, liver and muscle tissues of biological specimen of Rohu and Mrigala fish species.

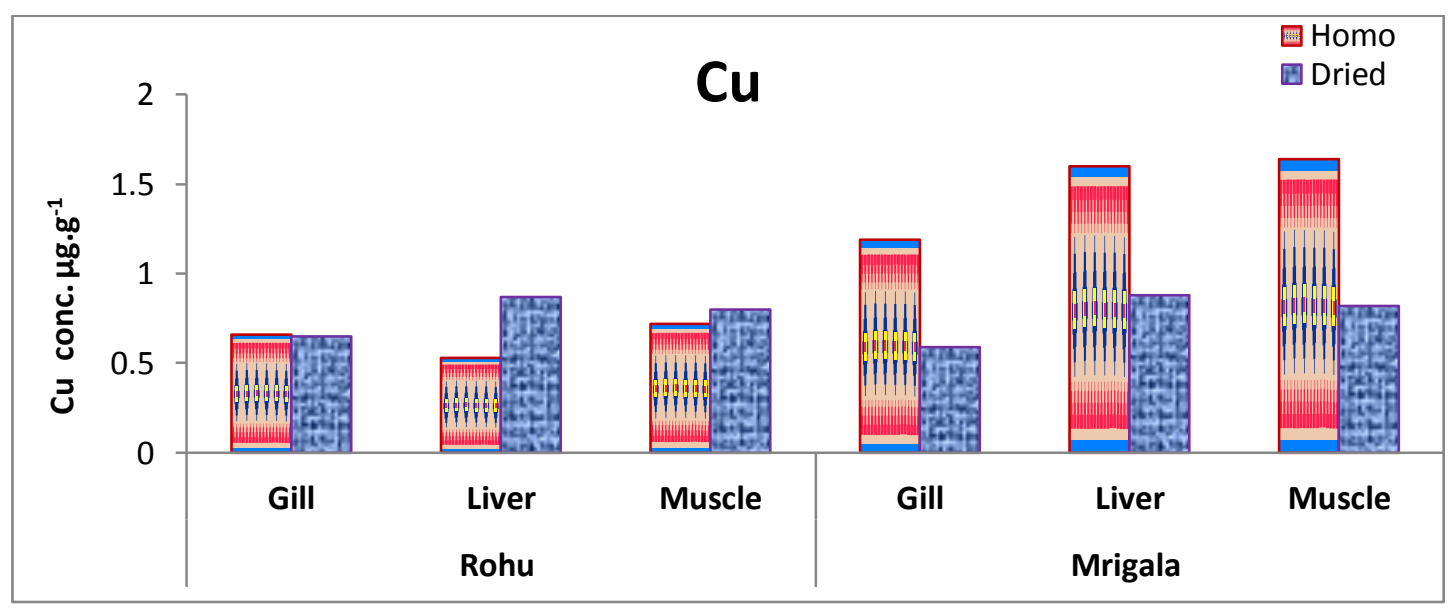

Figure 4: Comparison of average copper concentrations in gill, liver and muscle tissues of biological specimen of Rohu and Mrigala fish species.

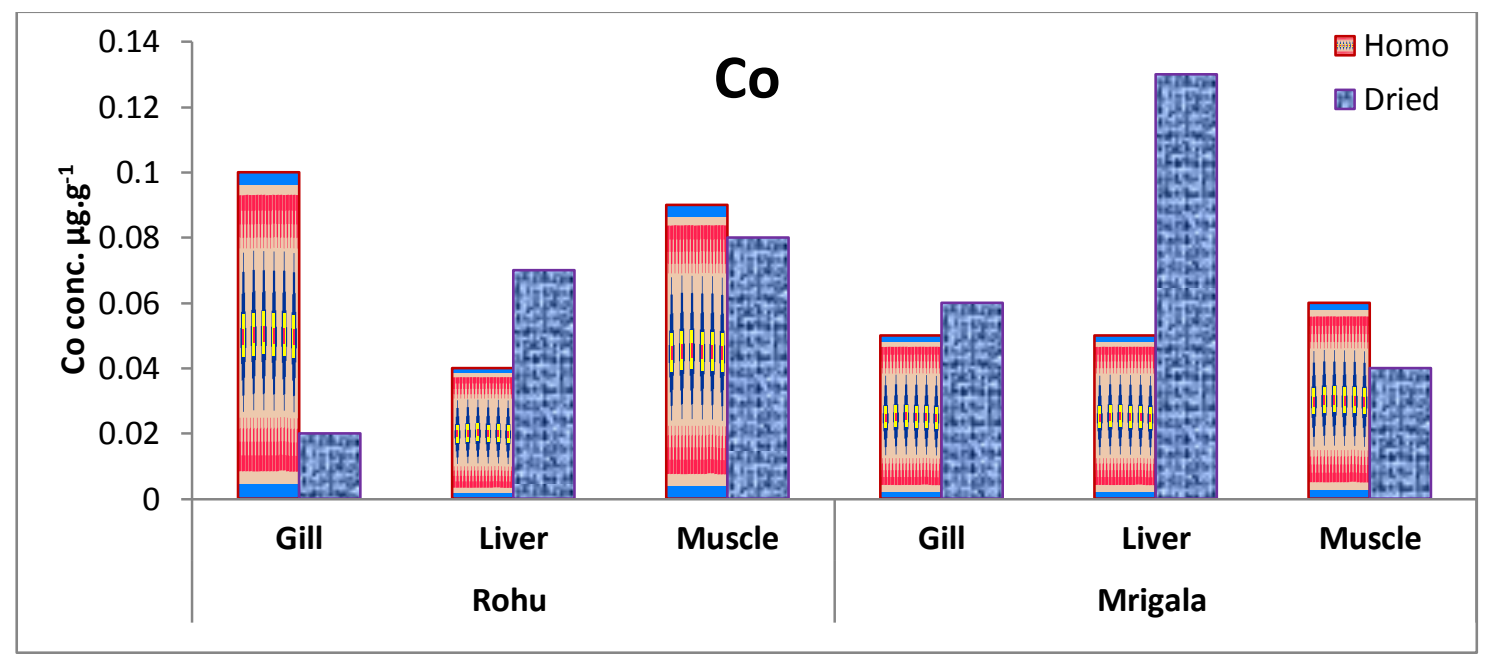

Figure 5: Comparison of average cobalt concentrations in gill, liver and muscle tissues of biological specimen of Rohu and Mrigala fish species. 


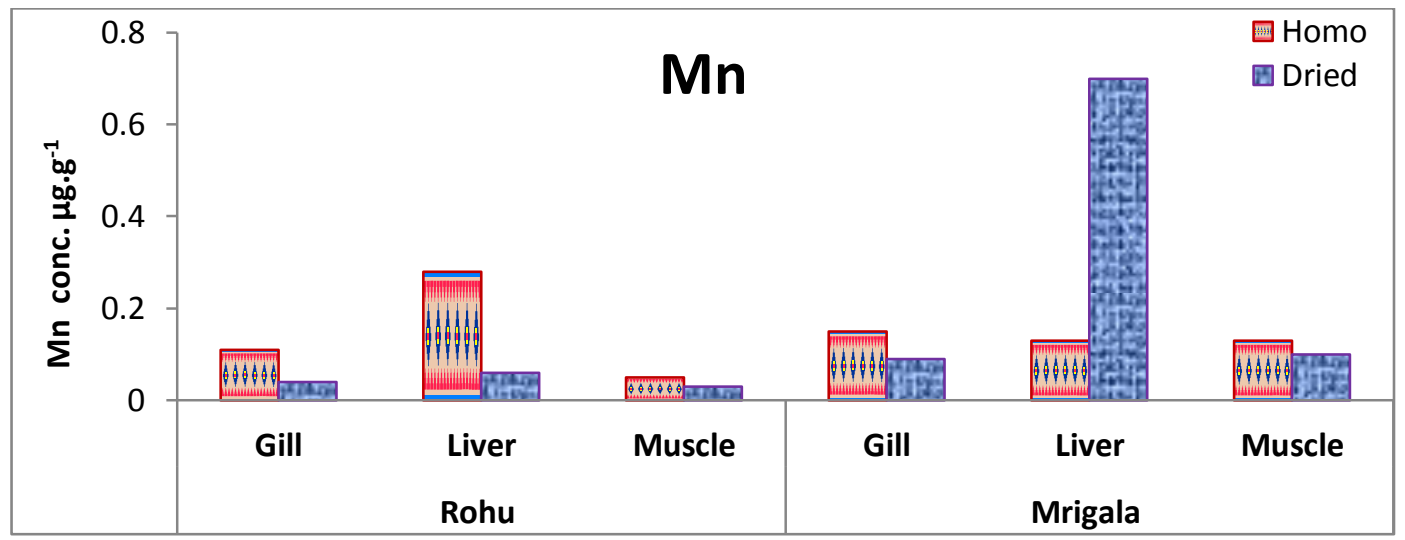

Figure 6: Comparison of average manganese contents in gill, liver and muscle tissues of biological specimen of Rohu and Mrigala fish species.

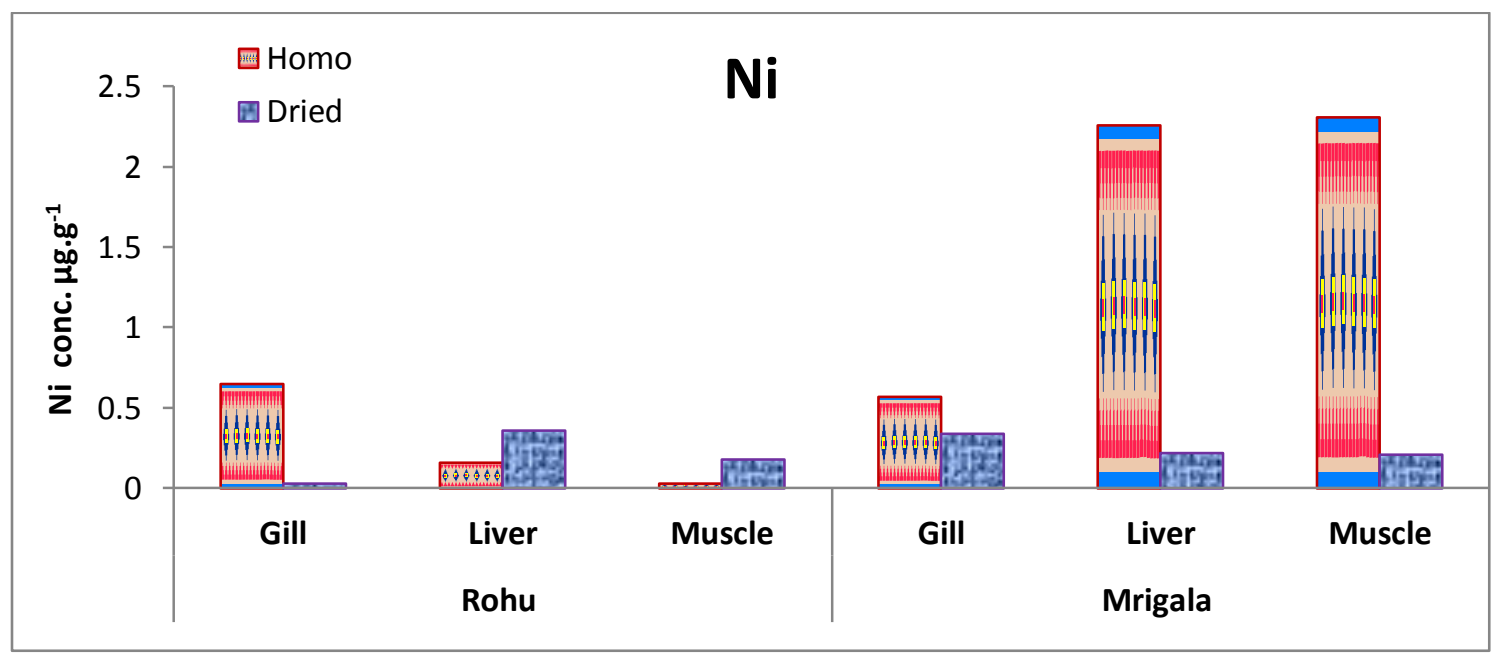

Figure 7: Comparison of average nickle contents in gill, liver and muscle tissues of biological specimen of Rohu and Mrigala fish species.

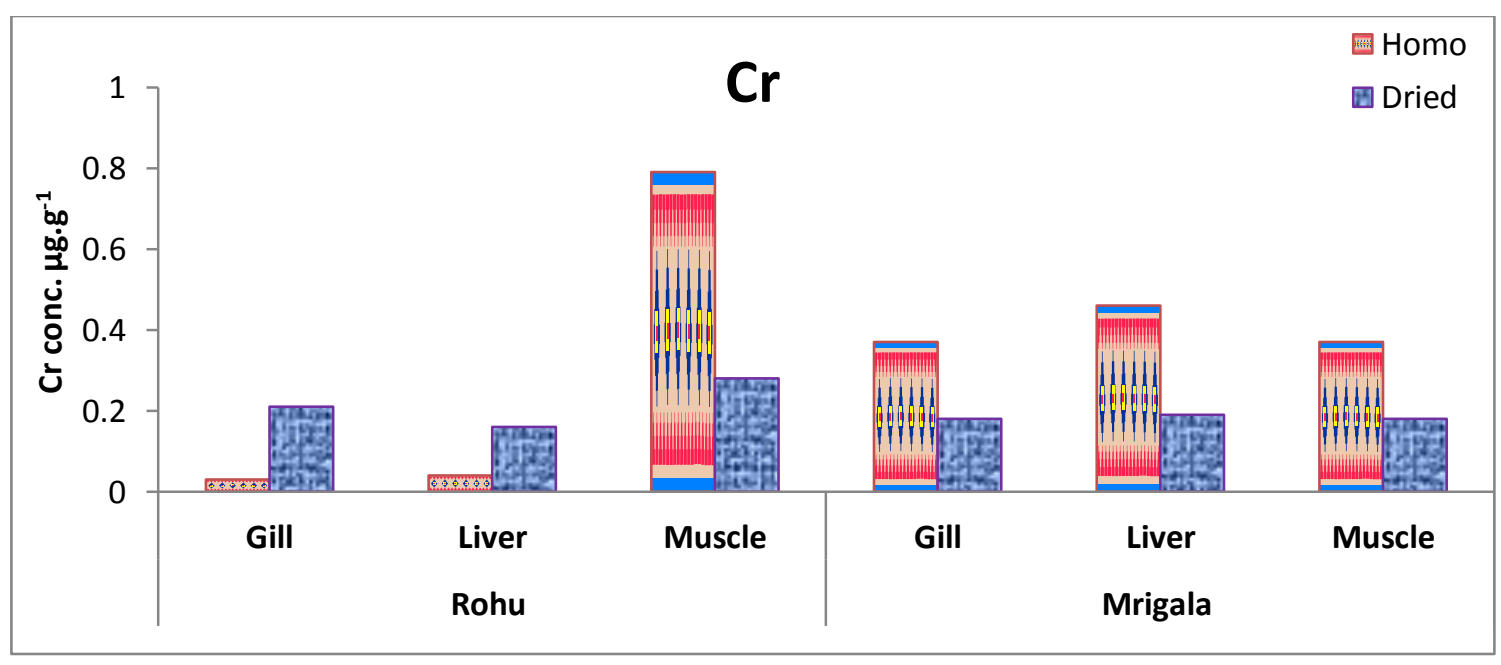

Figure 8: Comparison of average chromium contents in gill, liver and muscle tissues of biological specimen of Rohu and Mrigala fish species. 
Higher concentrations of Nickle were observed in Liver and muscle tissues of homogenous samples of Mrigala fish as compared to dried samples. Very minute concentrations of $\mathrm{Ni}$ were observed in homogeneous and dried samples of liver and muscle of Rohu fish in comparison to gill tissues. The concentration of $\mathrm{Ni}$ in various organs of Rohu and Mrigala fishes is given in Figure-7.

Figure-8 shows the concentration of chromium in various organs of both fish species in homo and dried samples. It is observed that the muscle tissues contained highest concentrations of chromium as compared to that of gill and liver tissues. In the organs of both fish species the concentration of chromium and lead was not detected.

It is observed the level of all the elements analyzed in different organs of Rohu and Mrigala fish were found within WHO specified limits. Fresh water contaminants like $\mathrm{Fe}, \mathrm{Cu}, \mathrm{Co}$, and $\mathrm{Ni}$ in the freshwater of Sindh was studied by Qasim and Jakhrani (2017), they concluded the concentration of these metals was within the safe limit. Prolonged exposure to low level of toxic metals causes kidney problems (Satarug et al. 2000). In humans, prolonged exposure to zinc can lead to deficiencies in iron and copper, vomiting, nausea, headache, fever, abdominal pain and the possible carcinogenicity of zinc is not reported (Fosmire, 1990).

\section{Conclusion}

In present study levels of various trace and toxic elements like $\mathrm{Fe}, \mathrm{Ni}, \mathrm{Cu}, \mathrm{Co}, \mathrm{Mn}, \mathrm{Zn}, \mathrm{Cr}, \mathrm{Cd} \& \mathrm{~Pb}$ in gill, liver and muscle tissues of Rohu (labeo rohita) and Mrigala (cirrhinus mrigala) fish species of Indus River at Guddu Barrage were investigated. The fish samples were collected and processed in the Laboratories of Institute of Chemistry, Shah Abdul Latif University, Khairpur, Sindh, Pakistan. Analysis was carried out using a double beam Atomic Absorption Spectrophotometer. It was concluded that the concentration of trace elements was found within the acceptable limits for human consumption set by WHO. Less concentration shows that the river water was less polluted possibly due to lack of rain fall since long time at the study area which might have drained the effluents from the industries into the river. It was a good indication for consumer of these fishes of the study area. The observed concentration order of trace and toxic metals was noted as $\mathrm{Fe}>\mathrm{Cu}$ $>\mathrm{Cr}>\mathrm{Ni}>\mathrm{Zn}>\mathrm{Co}>\mathrm{Mn}$ and $\mathrm{Fe}>\mathrm{Cu}>\mathrm{Ni}>\mathrm{Zn}>\mathrm{Cr}$ $>\mathrm{Mn}>\mathrm{Co}$ respectively, in homogenious and dried samples of labeo rohita whereas the order was found as $\mathrm{Fe}>\mathrm{Ni}>\mathrm{Cu}>\mathrm{Cr}>\mathrm{Zn}>\mathrm{Mn}>\mathrm{Co}$ and $\mathrm{Fe}>\mathrm{Cu}>$ $\mathrm{Ni}>\mathrm{Zn}>\mathrm{Cr}>\mathrm{Mn}>\mathrm{Co}$ correspondingly, in homogeneous and dried samples of cirrhinus mrigala fish samples.

\section{Acknowledgement}

The authors are thankful to the Institute of Chemistry, Shah Abdul Latif University, Khairpur Mir's, Sindh, Pakistan for providing facilities to carry out the present research work.

\section{Conflict of Interests}

The authors have not declared any conflict of interests.

\section{References}

1. Adam SM, 2002. Biological Indicators of Aquatic Ecosystem Stress". "American Fisheries Society".

2. Ali Muhammad Yousafzai, Douglas P, Chivers, Abdur Rehman Khan, et al., 2010.. "Comparison of Heavy Metals Burden in Two Freshwater Fishes Wallago attu and Labeo dyocheilus With Regard to Their Feeding Habits in Natural Ecosystem". Pakistan J. Zool 42:537-544.

3. Chattopadhyay B, Chatterjee A and Mukhopadhyay SK, 2002. Bioaccumulation of Metals in the East Calcutta Wetland Ecosystem. Aquatic Ecosystem Health Management 5: 191-203.

4. Canli M and Atli G, 2003. The relationships between heavy metal $(\mathrm{Cd}, \mathrm{Cr}, \mathrm{Cu}, \mathrm{Fe}, \mathrm{Pb}, \mathrm{Zn})$ levels and the size of six Mediterranean fish species. Environ Pollut. 2003;121:129-36.

5. Dural Mmz, Goksu L, Ozak A, et al., 2005. Lead and Cadmium in Stone Loach (Noemacheilus Barbatulus L.) From Three Rivers in Derbyshire. Ecotoxicology and Environmental Safety 18: 35-58.

6. Eneji I, Shaíato SR, and Annune PA, 2011. Bioaccumulation of Heavy Metals In Fish (Tilapia Zilli And Clarias Gariepinus) Organs From River Benue, North $\tilde{N}$ Central Nigeria. Pak. J. Anal. Environ. Chem., 12:25-3.

7. Long Er, Field, McDonald D, 1998. "Predicting Toxicity in Marine Sediments with Numerical Sediment Quality Guidelines. Environ", Toxicol. Chem. 17: 714-727.

8. Fosmire GJ, 1990. Zinc toxicity. American Journal of Clinical Nutrition, 51, 225.

9. Idodo-Umeh 2003. Freshwater Fishes of Nigeria Taxonomy, Ecological Notes, Diet and Utilization. Idodo-Umeh Publishers Ltd. Benin City. p. 234.

10. Indrajit Sen1, Ajay Shandil1 and V. S. Shrivastava. (2011). Study for Determination of Heavy Metals in Fish Species of the River Yamuna (Delhi) by Inductively Coupled PlasmaOptical Emission Spectroscopy (ICP-OES). Advances in Applied Science Research. 2 (2): 161-166.

11. Jezierska, B., \& Witeska, M. (2001). Metal toxicity to fish. University of Podlasie. Monografie No. 42.

12. Kakulu S.E., Osibanjo O. and Ajayi S. O. (1987). Trace Metal Content Of Fish And Shellfishes Of The Niger Delta Of Nigeria. Environ. Int. 13: 247-251.

13. Kargın, F. (1996). Seasonal Changes in Levels of Heavy Metals in tissues of Mullus barbatus and Sparus aurata collected from Iskenderun Gulf (Turkey). Water, Air and Soil Pollution, 90, 557-562.

14. Koldewey H., Cliffe A., \& Zimmerman B. (2013). Breeding Programme Priorities and Management Techniques for Native and Exotic Freshwater Fishes in Europe. International Zoo Book (47), 93-101.

15. Maitland P. S. and Lyle A.A (2013). Conservation of the Freshwater Habitats and fishes In the Western Ghats of India. International Zoo book, (47), 71-80.

16. Malik N., Biswas A.K., Qureshi T.A., Borana K. and Virha R. (2008). Bioaccumulation of heavy metals in fish tissues of a freshwater lake of Bhopal. Environ Monit Assess, 160(14):267-276.

17. Mendil M., Uluozlu, Hasdemir O.D., Tuzen E.M., Sari H. and Suicmez M. (2005). Determination of trace metal levels in seven fish species in lake in Tokat, Turkey. Food Chemistry, 90 (1-2), pg. 175-179."(2005). 
Elemental Assessment in Economically Important Cirrhinus Mrigala and Labeo Rohita Fish Species Captured from Indus River at Guddu Barrage, Sindh, Pakistan

18. Muhammad Qasim \& Mushtaque Ali Jakhrani (2017): Physicochemical and elemental contamination assessment in groundwater samples of Khairpur Mir's, Pakistan, Human and Ecological Risk Assessment: An International Journal, DOI: 10.1080/10807039.2016.1277415.

19. Naeve H. (1994). "Review Of Pollution in the African Aquatic Environment. Food and Agriculture Organization of United States, Rome. Pp.35.

20. Njuguna S.G. and Kitur E. C. (2014). Bioaccumulation Of Heavy Metals In Clarias Gariepinus And Oreochromis Spirulus From Masinga Reservoir, Kenya. Journal of Environmental Science, Toxicology and Food Technology, 8(10): 58-63

21. Nzeve J., Njuguna S.G., and Kitur E. C. (2014). Bioaccumulation Of Heavy Metals In Clarias Gariepinus And Oreochromis Spirulus From Masinga Reservoir, Kenya. Journal of Environmental Science, Toxicology and Food Technology, 8(10): 58-63.

22. Reid, McG. G. (2006). Developing the research potential of zoos and aquaria. Proceedings of the 3rd International Conference on Zoo Research:Animals, Zoos and Conservation, 8-9 June 2006.,Poznan, Poland.

23. Satarug, S., Haswell-Elkins, M. R., \& Moore, M. R. (2000). Safe levels of cadmium intake to prevent renal toxicity in human subjects. British Journal of Nutrition, 84, 791-802.

24. Shaíato S.R. and Annune P. A. (2011). Bioaccumulation of Heavy Metals In Fish (Tilapia Zilli And Clarias Gariepinus) Organs From River Benue, North Ñ Central Nigeria. Pak. J. Anal. Environ. Chem., 12(1, 2): 25-3.

25. Stanburg B.J., Wyngarder B.J. and Dowal D.S.F. (1978) "The Metabolic Basis of Inherited Diseases". McGraw-Hill Book Company, New York, 1474-150.

26. Storelli M., D'ddabbo R., Marano C. Bruno, and Marcotrigiano G.O. (2005). Trace Elements in Loggerhead Turtles (Caretta Caretta) From the Eastern Mediterranean Sea: Overview and Evaluation. Environmental Pollution, $135,163-170$. 